\title{
Depreciation Capital as a Source of Financing of Mining Companies Activities
}

Agata Sierpińska-Sawicz ${ }^{1}$ and Maria Sierpińska²

ABSTRACT

The issue discussed in the paper is highly relevant and topical in economic practice because of changes in the recognition of certain assets and their depreciation. The author's research established that depreciation write-off in financial terms constitute capital comprising two components: depreciation and the tax shield effect. The non-tax shield is more important relative to other tax shields because the vast majority of entities in the raw materials industry own assets which are depreciated for the purposes of balance sheet accounting and tax accounting. As a cost depreciation, on the one hand, reduces the financial result and on the other, generates additional operating cash flows. Depreciable assets account for a large portion of coal companies'assets. In addition, due to the implementation of IFRS 16 on leasing their share increased as did the amount of depreciation. Hence, its share in operating cash flows in Polish coal companies is slightly higher than in global companies. An overwhelming part of the additional depreciation arising from the inclusion in the assets reported in the balance sheet of assets used based on contracts of lease, lending or rental does not reduce the tax basis and does not constitute a tax shield. Consequently, it creates a disparity between the gross profit/loss and taxable income, thereby increasing the effective tax rate. An increase in the depreciation level in coal companies facilitates maintenance of liquidity and provides financing for investment projects and improves debt servicing, especially in times of declining financial result when coal prices are low.

KEY WORDS: $\quad$ Amortization, depreciation, capital expenditures,operating cash flow, firm financing.

JEL Classification: G32.

Poznan University of Economics ${ }^{1}$

University of Economics and Human Sciences in Warsaw, Poland ${ }^{2}$

\section{Introduction}

The capital needed to finance a company's current operations and its investment projects may come from various sources. These sources can be classified based on various criteria. The most common criterion is the source of the capital. In this classification a distinction is made between internal and external financing. The depreciation of fixed assets and amortization of intangible assets constitute an important source of internal financing. They are a source of cash generated to finance

Correspondence concerning this article should be addressed to:

Agata Sierpińska-Sawicz Poznan University of Economics, Al. Niepodległości 10,61-875 Poznań, Poland

E-mail: agata.sierpinska-sawicz@ue.poznan.pl replacement investments. The importance of depreciation (where the term 'depreciation' is used, it also refers to amortization of intangible assets, unless amortization is itemised specifically) as a source of financing grows especially strongly during an economic crisis, when companies are hamstrung with limited access to bank loans. They can then allocate funds originating from depreciation to the financing of their current operations, making it easier for them to maintain liquidity. The issue of depreciation has gained prominence after the 2019 implementation of International Financial Reporting Standard 16 (IFRS 16) on leasing. On the heels of the implementation, a significant increase in accrued depreciation was noted in Polish coal 
companies. All leased assets, regardless of their type, and all assets used based on contracts of lending, lease, rental, and servitude came to be valued and recognised in the balance sheet as profit generating assets. Subsequently, companies' depreciable assets increased. On the one hand, it reduced companies' profit, as depreciation costs rose, but on the other, it generated funds for the simple replacement of assets. From time to time, these funds can be used to service current debt or investments.

The paper attempts to illustrate the role of depreciation as a source of operating cash flows used to finance investments and to pay off debts. Four working hypotheses were formulated.

H1. Polish coal companies' fixed assets are depreciated on a scale similar to global companies

$\mathrm{H} 2$. Their average annual depreciation rates do not differ substantially from the rates applied by global companies.

H3. In Polish coal companies, depreciation creates operating cash flows to a greater extent than in global companies.

H4. In coal companies, depreciation is an important source of capital expenditure financing.

\section{Depreciation as Capital}

To raise the resources needed to run a business, the company must have adequate capital at its disposal. Capital is constituted by that portion of resources that brings its owner the expected income (Smith 2007, p. 306). According to I. Fisher, capital is constituted by each and every resource - anything of value that is used to produce goods or services (Hendriksen \& Breda, 2002). Hence, in economics, the concept of capital encompasses those categories of assets that are used to produce goods or provide services. Capital includes tangible assets (buildings, machines and equipment, road infrastructure) and intangible assets (technologies and human capital) (Glautier et al., 2011, p. 429, Grabiński, 2016, p. 35). However, T. Piketty excludes human capital from the definition of capital. He argues that capital is the entirety of assets that can be owned and exchanged on the market and includes, in particular, all real estate capital and financial and organizational capital used by the company and public administration (Piketty, 2015, p. 63). For an entity to operate, it needs to have the right capital structure.
From a financial point of view, it also means the potential to generate future profits. The amount of capital depends on a combination of an entity's various resources that affect its ability to obtain future economic benefits (Grabiński, 2016, p. 38; Fan et.al., 2021, p. 24).

In finance, capital is construed as funds entrusted to a company by its owners and creditors (Graham \& Harvey, 2001 Janasz, 2008). When capital is being invested in a company, the creditors and owners take into account the income that their investment can generate, namely., interest rates and dividends, while shareholders also look for the capital gains resulting from increased shareholder value (Fith, 1995; Feld \& Heckemeyer, 2013 p. 2652). Capital is the aggregate value of the assets in the company, which is entered in its balance sheet on the liabilities and equity side. In microeconomic terms, the general definition of capital is not used. Instead, two capital-related concepts are employed:

- real (tangible) capital, that is, a technologically determined amount of goods that are used to produce other goods,

- financial (cash) capital, that is, the sum of financial resources allocated to investments.

The general concept of capital refers to finance capital and represents the sum of money spent on investment. This category includes depreciation. By charging a part of the value of assets to costs, the company generates funds that are used for replacement investments (Sigidov et al., 2016).

The concept of depreciation capital should be based on the definition of depreciation as a source of financing of a company's activities and on the definition of capital. Financial resources generated by depreciation write-offs constitute capital as they are used to finance the production of goods or provision of services. Broadly speaking, in accounting, capital is defined as a source of financing of a company's activities and is recognised as a liability in the balance sheet, so depreciation is not capital in the light of the Accounting Act, as it cannot be entered as a liability in the balance sheet. However, M. Dobija points out that the theoretical foundations of accounting cannot be shaped either by detailed standards or provisions of the Accounting Law (Dobija, 2002). He argues that depreciation indirectly influences the equity components of the balance sheet (by affecting the value of fixed assets 
and profit) and external capital, hence it can be treated as capital.

As a result of depreciation write-offs, the value of the capital tied up in fixed assets gradually decreases over time. The amount reducing the initial value of the asset is transferred in the form of depreciation to the value of the product and then returns to the company in the form of liquid funds from sales revenues. There is a gradual accumulation of the capital released from a given asset. The process of accumulation of released capital from one object considered on a timeline can be defined as serial accumulation, and in terms of all fixed assets - as a serial-parallel accumulation of released capital. This is an investment-free process that changes the structure of the company's assets. As a result, the capital that was tied up in fixed assets over a long time is gradually being released and can be reused. The average capital tied up over the entire period of an asset's useful life totals $1 / 2$ of its initial value. This means that half of the capital tied up in the fixed asset becomes available to the company during the asset's useful life. This capital can be used to finance development investments. The possibility of reinvesting the released capital is the basis for bolstering production potential. The effect of increasing the potential is further intensified if the company simultaneously exploits and depreciates many high value fixed assets (Głodek, 2001; Fan et al., 2012).

Depreciation capital (DC) is the sum of two components: balance sheet depreciation also known as accumulated depreciation (AD) and savings arising from inclusion of tax depreciation in tax deductible costs, namely, from the depreciation tax shield (DTS) (Iwin-Garzyńska, 2018, p. 95):

$\mathrm{DC}=\mathrm{AD}+\mathrm{DTS}$

The essence of the depreciation tax shield and its importance for the replacement of fixed assets arises directly from legal regulations. The depreciation calculated on the basis of the provisions of the Income Tax Act is included in the tax-deductible costs that reduce the tax basis. This means that through fiscal solutions, the state participates in the process of replacing used fixed assets. The real possibilities of raising depreciation capital in the company depend on system's financial solutions that determine the amount of de- preciation charges included in tax deductible costs. By reducing the tax basis, depreciation is a non-interest tax shield. An interest tax shield relates to interest on external capital, which also reduces the tax basis. The monetary value of tax shields is equal to the product of the deduction amount and the applicable tax rate (Sierpińska, 2021, p.127). The presence of non-interest tax shields in a company may crowd-out interest shields if entrepreneurs perceive them as substitutes. (Leszczyłowska, 2018, p. 359). When debt financing is motivated by fiscal considerations, non-interest tax shields may be a substitute for interest shields and contribute to curtailing debt financing.

\section{Fixed Assets Depreciation Methods}

Depreciation is the spreading of the value of a depreciable fixed asset over its useful life and charging it to the company's cost in order to recoup the costs incurred to obtain the asset, thereby creating a fund for its replacement after its useful life ends. "American standards additionally emphasise the necessity of rationality, which is understood as the use of such a formula for the spreading of the depreciable value which is well thought-out (logical) and acceptable to another accountant guided by objective reasons." Authors also share the view that depreciation is a cost that arises because of a subjective reduction in the value of fixed assets (Sigidov et al., 2016; Maruszews$\mathrm{ka}, 2018$ ). Indicating cost as a feature of depreciation results from the fact that it is construed as a gradual process of transferring the value of fixed assets to the products or services they are used to make or provide respectively. Thus, it is assumed that the translocated (transferred) value of a fixed asset is the equivalent of its wear and tear in the production of goods or provision of services (Maruszewska, 2018).

Depreciation has at least a triple function in the company (Iwin-Garzyńska, 2005):

- write-off-related to reflect the wear and tear and replacement of fixed assets, it reflects the loss of fixed assets' value,

- cost-related, as it is a cost for the company and its inclusion in costs deductible for tax purposes reduces the tax basis, and thus the level of income tax.

- financial, because it is a tool for accumulating money resources.

Thus, depreciation not only reflects the fixed as- 
sets' impairment, but is primarily a tool for generating cash funds that can be later allocated to capital expenditure, constituting a source of internal financing. Through its flexible use, cumulative depreciation determines the functioning and development of a given company (Mądra-Sawicka, 2018). Regardless of the legal form of the company and its depreciation method, the depreciation fund remains at its sole disposal.

The basis for calculating depreciation is the initial value of the fixed asset. It is constituted by the purchase price, the cost of manufacturing or building a fixed asset by the company itself, fair (market) value when a fixed asset is obtained as inheritance, donation or otherwise on a free-of-charge basis, the value resulting from valuation in the case of fixed assets received in kind, the value resulting from leasing contracts when a fixed asset is taken for use under leasing contracts (Aleszczuk, 2012, p. 148). During their operation, the initial value of fixed assets may change because of their improvement and modernisation, and sometimes because of the official revaluation of fixed assets. The amount of a fixed asset depreciation depends not only on its valuation and the selected depreciation method, but also on its determined useful life and estimated residual value.

The amount of accrued depreciation depends on:

- historical cost, constituting the basis for the initial recognition of assets that are depreciable; it is mainly the purchase price of the asset or the cost of its manufacture,

- assumed useful life of the depreciable asset,

- estimated residual value of the depreciable asset,

- depreciation method used.

Three of the four factors mentioned above involve estimations. An asset's useful life is determined not only based on its physical wear and tear (in the case of fixed assets) or legal constraints (in the case of intangible assets), but may also depend on (Maruszewska, 2018, p. 140):

- speed of technological change in the industry,

- predictions of progress in implementing change and innovation in the entity's technological processes,

- assumptions underlying changes in demand as evidenced by the market.

The residual value, estimated at the time of the initial recognition of an asset in the books, may also be estimated variously in different situations, because it is based, for instance, on the expected net realisation value of a similar asset, that is, an asset with a similar wear and tear at the end of its exploitation and which has operated under similar conditions in which the depreciable asset in question will operate.

Companies can use different depreciation methods to spread the cost of depreciable fixed assets over their useful life. The methods of their application are laid down in the Accounting Act and the Corporation Income Tax Act.

The Accounting Act provides that when the depreciation method is being chosen, consideration should be given, first, to the fixed asset's useful life, which is conditioned by the number of shifts it works, the pace of technological and economic progress, the efficiency of the fixed asset, legal or other restrictions on its useful life, and in the case of liquidation, to the expected net selling price of a significant remainder of the fixed asset. The Corporation Income Tax Act regulates the principles of determining depreciation for the purposes of calculating income tax in a more restrictive manner, for example, by imposing constraints on determination of discretionary depreciation rates. A suitable example is provided by the dependence of the depreciation period on the initial value of fixed assets, which usually means the purchase price or production cost of a given asset, less any residual value. (Cygańska, 2014, p. 10).

The Accounting Act does not dictate which method/s are to be used if the principle of fair presentation of the degree of asset wear is adhered to. On the other hand, the Corporation Income Tax Act allows the use of three methods of depreciation write-offs classified as tax deductible costs. These methods are one-time, straight line, diminishing balance method.

The one-off method is based on a one-off inclusion of the value of the acquired fixed asset in the tax-deductible costs. Since 2018, entrepreneurs have been able to include PLN 10,000 in the tax-deductible costs in the month a given fixed asset is put into use. Although Article 32.6 of the Accounting Act allows for a one-off write-off of fixed assets which have a low initial value, this must not distort the true picture of the entity's financial situation. One-off write-offs should not be made either by small companies for 
which each fixed asset related directly to costs distorts the financial result, or by large companies which buy large amounts of small value fixed assets whose aggregate value can be quite high.

The straight-line method is the primary depreciation method used by companies. It consists in evenly spreading the depreciable value of a fixed asset over the period of its useful life. Period after period, the same amount is written off, using a fixed rate. The tax law also allows taxpayers to reduce or increase the depreciation rates given in a schedule of rates, starting with the first of each subsequent fiscal year, or with the month in which these assets were put into use. Increased depreciation rates may be used to calculate depreciation of buildings and structures used in worse or inferior conditions, fixed assets subject to rapid technical progress and used more intensively relative to average conditions or conditions demanding unique technical efficiency. The company also has the option of reducing the depreciation rate specified in the annex to the Income Tax Act. In lowering the rate, the entity may be guided by the principle of adequacy of depreciation costs to the productivity of the fixed asset.

However, because of the reduction in the depreciation rate, the tax basis for the calculation of income tax increases and thus the tax effect of depreciation diminishes. From the point of view of the amount of non-interest tax shield, this is a disadvantage for the company. The legislator afforded companies the option of using discretionary depreciation rates for improved or used components of fixed assets. The rates for these assets are set by the company itself, but the depreciation period resulting from the rate applied by them cannot be shorter than that which the Act provides for for specific groups of fixed assets. It should be emphasised that the possibility for the company of using discretionary rates is extremely limited. The rates were introduced to prevent abuse by companies, but at the same time the group of entities that could take advantage of this preferential option of fixed asset depreciation was narrowed. Increased depreciation rates within the bounds permitted by the Tax Law are calculated using the straightline method of depreciation (Iwin-Garzyńska, 2018).

The third depreciation method permitted by the Polish Tax Law is the diminishing balance method.
Depreciation write-offs in the initial periods of a fixed asset's use are higher than the average determined using the straight-line method and are gradually declining over time. This is an attractive proposition for companies, as increased write-offs reduce taxable income and lower income tax payable. In Poland, accelerated depreciation of the diminishing balance type may be applied to machinery and equipment classified by the Central Statistical Office as groups 3-6 and 8 in the Classification of Fixed Assets and applies to means of transport other than passenger cars. In the first year of use, the company may apply a fixed asset depreciation rate increased by a factor of 2 or less, and in the following tax years it makes write-offs from the initial value reduced by the hitherto depreciation write-offs. When applying the declining method, the coefficient by which the depreciation rate may increase must not exceed 3 , but it applies exclusively to fixed assets that can be depreciated by this method. Such accelerated depreciation can be applied in a plant located in a commune with a particularly high risk of high structural unemployment or in a commune threatened with recession and social degradation. The regulations governing the diminishing balance method also contain preferential provisions for entrepreneurs who started their business activity and for 'small taxpayers'. These entrepreneurs can opt to use depreciation including a one-off write-off up to $100 \%$ of the initial value of the fixed asset in the first tax year (Accounting Act, 1992, Art. 16k). This applies to fixed assets belonging to groups 3-8 of the Classification of Fixed Assets, including machinery, equipment and means of transport other than passenger cars. Under this method, the total amount of depreciation write-offs made on fixed assets registered each year may not exceed the equivalent of EUR 100,000.

The company enjoys autonomy in selecting one of the depreciation methods before commencing depreciation and uses the method to fully depreciate a given fixed asset. A possible adjustment of depreciation write-offs is allowed only in exceptional situations, for example, when the company wrongly determined the amount of depreciation, incorrectly determined the initial value of fixed assets, applied the wrong rate, but only when the straight-line method and rates included in the annex to the Act are used. It 
cannot change the method when the course of an asset's depreciation runs (Iwin-Garzyńska, 2018).

Pursuant to the Corporation Income Tax Act (CIT), depreciation write-offs are made from the first month following the month in which the fixed asset enters company's records. Depreciation is complete when the asset is designated for sale (or included in the group of assets held for sale) or when it is removed from the balance sheet - whichever is earlier. Therefore, it can be concluded that the end of depreciation write-offs does not take place when the asset is no longer needed or when it has been decommissioned, unless it has already been fully depreciated (Olejko, 2014). The Accounting Act does not specify when the company should start to depreciate its assets. However, companies try to start tax and balance sheet depreciation at the same time to avoid differences between gross profit and the tax basis. These differences affect the financial result and income tax. This, in turn, necessitates separate records for tax and balance sheet purposes as well as determination and disclosure of deferred income tax. (Paff et al., 2018).

\section{Research Methods}

The authors studied data obtained from Thomson Reuters Eikon data set of 12 global mining concerns listed on several stock exchanges. These concerns can be divided into two groups. The first consists of entities with diversified mining activities. In addition to coal, they also extract other raw materials in the area for which the concern has obtained a mining concession. This group includes the British concern Anglo American, Australian concern Rio Tinto, Brazilian company Vale SA, Russian corporation Mechel.

Britain's Anglo American extracts raw materials on all continents. Apart from coking and steam coal, it mines copper, nickel, iron ore and diamonds. The Anglo-Australian company Rio Tinto is the second largest mining corporation in the world right after BHP. BHP prospects for various types of minerals. This Brazilian mining company is the world's largest producer of iron ore and nickel. It also produces manganese, ferroalloys, copper, bauxite, potassium, and cobalt. It owns nine power plants and has a large network of railways, ships and ports that facilitate the transport of manufactured products. Russia's globally active Mechel coal and metallurgical corporation produces coal, iron ore, steel, rolled products, ferroalloys, heat, and electricity. All the Group's companies operate within a single production chain - from raw materials to high addedvalue products.

The second group consists of entities focused on the coal mining segment. The largest entities in this group are the American companies Arch Resources and Peabody. Arch Resources extracts, processes and sells low-sulphur coal in the United States, but also exports it to China, Australia, and the United Kingdom. The second US coal company, Peabody, is the world's largest private coal mining company. Its customers include power plants, steel producers and industrial plants. Coal India is the world's largest state-controlled company, supplying $82 \%$ of the coal used by the Indian economy. Australia's Whitehaven Coal Ltd. mines steam and coking coal and exports it to buyers around the world. Similarly, the Russian company Raspadskaya is in the market for coal mining and transport alone. The Polish companies LWB SA and JSW SA also belong to the group of entities whose activity is focused purely on coal mining, processing, and transport. LWB $\mathrm{SA}$ is in a logistical link with a power plant. On the other hand, JSW SA focuses mainly on the extraction of coking coal, some of which is processed into coke and some delivered to coking plants in the metallurgical industry.

Based on data from the financial statements of the companies surveyed, several relationships were calculated showing the extent to which depreciation constitutes capital used to cover investment expenditure and to supplement funds needed to repay debts. The following relationships were calculated for the period of five years:

- The rate of depreciation of an asset as the ratio of the accumulated depreciation to the gross value of depreciable assets. It shows the scope of capital needs for its replacement. A high degree of asset depreciation indicates the need to renew assets and make capital expenditures originating in depreciation.

- Relationship of annual depreciation as reported in the cash flow statement to the gross value of fixed assets as reported in the balance sheet of the analysed companies. The ratio shows in percentage terms the annual return on expended capital.

- The share of depreciation in operating cash flows as the ratio of depreciation to the level of operating 
cash flows. The ratio shows the extent to which these cash flows are generated through depreciation and to what extent they are generated through the net financial result as well as changes in the net working capital requirement.

- The ratio of depreciation to capital expenditure shows what percentage of these expenses are covered by depreciation and how much comes from other sources of financing.

\section{Results of Empirical Research}

Table 1 shows the degree of accumulated write-off of fixed assets in the analysed mining companies. Coal India and Peabody Energy Corp report a lower level of fixed assets depreciation than the other companies. After the crisis on the coal market in 2014-2015, some companies underwent a thorough restructuring. For example, Arch Resources almost halved its fixed assets and disposed of fully depreciated and redundant assets.

As a result of these processes, the degree of accumulated write-off of assets declined from almost 78\% in 2016 to $13.4 \%$ in 2017. Restructuring processes were also carried out by Peabody Energy Corp. In the remaining mining companies, the degree of accumulated asset depreciation in 2019 ranged from $44 \%$ to
$58 \%$. In JSW, it was higher than in LWB, exceeding 58\% in 2017 and 2018, the highest among the analysed companies. Throughout the study period, in most mining companies the degree of accumulated depreciation of fixed assets was similar to the level reported by both Polish companies. Thus, the first research hypothesis was confirmed.

The ratio of annual depreciation to the gross value of depreciated assets presented in Table 2 indicates the percentage of the value of these assets charged to costs on a yearly basis. Average depreciation rates reflect how an entity's technical and financial operatives perceive the consumption of a depreciable asset and how its value should be allocated to products or services. Arch Resources Inc. uses exceptionally high depreciation rates, and recent years also saw the same at Peabody Energy Corp. This is partly due to the above-mentioned restructuring processes

The major differences relating to the amount of annual depreciation are due to mine type. In opencast mines, the so-called overburden is depreciated. Mines recognise it as an item of property, plant, and equipment, specifically as the so-called overburden stripping asset, namely, costs of overburden removal incurred at the production stage. The value of the as-

Table 1

Degree of Accumulated Write-off of Fixed Assets in Mining Companies in the Years 2015-2019

\begin{tabular}{lccccc}
\hline Company & $\mathbf{2 0 1 5}$ & $\mathbf{2 0 1 6}$ & $\mathbf{2 0 1 7}$ & $\mathbf{2 0 1 8}$ & $\mathbf{2 0 1 9}$ \\
\hline Anglo American PLC & 50.55 & 52.53 & 52.40 & 51.17 & 49.78 \\
Arch Resources Inc. & 75.74 & 77.57 & 13.36 & 24.18 & 26.26 \\
BHP Group PLC & 45.54 & 48.94 & 46.99 & 48.51 & 48.89 \\
Coal India Ltd. & 9.66 & 14.78 & 18.27 & 21.51 & 24.43 \\
JSWSA & 54.23 & 55.96 & 58.33 & 58.32 & 52.46 \\
LWB SA & 42.41 & 46.60 & 45.05 & 46.95 & 47.56 \\
Mechel PAO & 36.70 & 39.21 & 42.61 & 46.05 & 46.36 \\
Peabody Energy Corp. & 35.21 & 31.17 & 11.64 & 21.42 & 31.14 \\
Raspadskaya PAO & 47.53 & 43.02 & 43.37 & 44.77 & 57.98 \\
Rio Tinto PLC & 42.70 & 45.42 & 46.42 & 45.96 & 49.51 \\
Vale SA Brazilian & 31.21 & 34.23 & 36.97 & 40.07 & 44.22 \\
Whitehaven Coal Ltd. & 23.49 & 30.42 & 37.21 & 41.68 & 46.52 \\
\hline
\end{tabular}

Source: own calculations based on the balance sheets of mining companies retrieved from a Reuters database 
Table 2

Ratio of Depreciation to the Gross Value of Tangible Fixed Assets in Mining Companies in the Years 2015-2019

\begin{tabular}{|c|c|c|c|c|c|}
\hline Company & 2015 & 2016 & 2017 & 2018 & 2019 \\
\hline Anglo American PLC & 3.98 & 3.53 & 3.71 & 4.10 & 4.13 \\
\hline Arch Resources Inc. & 10.83 & 11.10 & 11.10 & 10.86 & 8.23 \\
\hline BHP Group PLC & 4.03 & 3.92 & 4.97 & 4.41 & 4.32 \\
\hline Coal India Ltd. & 9.66 & 7.66 & 6.62 & 6.60 & 5.79 \\
\hline JSW SA & 7.23 & 4.94 & 5.03 & 4.37 & 5.29 \\
\hline LWB SA & 7.67 & 6.95 & 6.01 & 6.56 & 6.19 \\
\hline Mechel PAO & 3.63 & 3.51 & 3.64 & 3.54 & 4.13 \\
\hline Peabody Energy Corp. & 4.00 & 3.33 & 11.64 & 11.01 & 9.74 \\
\hline Raspadskaya PAO & 4.63 & 3.78 & 4.17 & 4.75 & 4.37 \\
\hline Rio Tinto PLC & 4.36 & 4.44 & 3.78 & 3.85 & 3.86 \\
\hline Vale SA Brazilian & 4.05 & 4.41 & 4.11 & 3.91 & 4.38 \\
\hline Whitehaven Coal Ltd. & 2.11 & 2.59 & 2.44 & 3.16 & 3.12 \\
\hline
\end{tabular}

Source: own calculations based on the balance sheets of mining companies retrieved from a Reuters database

set arising from removal of overburden at the production stage is determined based on a model that considers, inter alia, the estimated value of the total $\mathrm{O}-\mathrm{C}$ ratio (ratio of the amount of overburden to carbon) and the actual annual $\mathrm{O}-\mathrm{C}$ ratio. This ratio is calculated as the relationship of the amount of overburden still to be removed to the coal resources still to be extracted from the date of application of Interpretation 20 of the International Financial Reporting Interpretations Committee 20 (IFRIC) (EU Commission Regulation) to the end of coal exploitation from a given coal seam. It is determined based on the best knowledge of the mine's technical services at the end of each financial year and may be amended as the exploitation progresses to reflect new information on the size of the exploited deposit and the manner of its structure. The overburden stripping asset is systematically depreciated using the natural method based on the amount of coal extracted from a given deposit component (PGE Group Consolidated Report for 2019 , p. 38). In addition, opencast mines include in the value of fixed assets the estimated costs of the excavated overburden as a portion of the reclamation cost after final excavations. The reclamation cost asset is systematically depreciated by means of the natural method based on the amount of coal extracted from the open cast. The differences in the recognition of certain assets between opencast and underground mines partially justify the differences in rates between JSW and LWB. In an opencast mine, the average rates are higher than in an underground mine.

The level of the applied depreciation rates is also influenced by the degree of diversification of companies' activities. This relates to different depreciation rates for different assets. In the group of companies surveyed, the British concern Anglo American, Australia' Rio Tinto, the Brazilian company Vale SA and Russia' Mechel Corporation have diversified activities. In addition to coal, they also extract other raw materials located in the area for which the concerns obtained a mining license. Anglo American extracts numerous raw materials on all continents. The Brazilian mining company is the world's leading producer of iron ore and nickel. It also produces manganese, ferroalloys, copper, bauxite, potassium, and cobalt. Russia's global coal and metallurgical corporation Mechel produces coal, iron ore, steel, rolled products, ferro-alloys, heat, and electricity. At the other extreme are entities focused on coal mining, and their diversification is the result of either coal processing processes, coal use in heating or auxiliary processes connected with mining processes. The largest enti- 
ties in this group include the American companies Arch Resources and Peabody, Coal India, Australia's Whitehaven, and Russia's Radspadskaya. The Polish companies, LWB SA and JSW SA, are focused only on coal mining, processing, and transport.

Comparing the average annual depreciation rates in Polish companies with the rates in global companies, one cannot but notice that they do not differ significantly from the rates revealed by global companies. They remain at an average level, which means that some global companies have higher rates, and some have lower. These observations confirm the second hypothesis assumed in the introduction.

Table 3 contains ratios showing the share of depreciation in operating cash flows. The ratios illustrate the extent to which depreciation generates cash flows that are intended to cover capital expenditure or debt repayment. These cash flows include the net financial result, depreciation, and changes in the demand for net working capital. They result from changes in the level of inventories, receivables, and short-term liabilities. Each increase in inventories and receivables eats into a part of the funds originating in financial result and depreciation. Conversely, any decline in the value of these current assets frees up cash and increases operating cash flow. An increase in shortterm liabilities, however, increases the level of generated funds, whereas a decrease means that the funds were used to pay off debts. Changes in the demand for net working capital result from changes in economic activity, expressed as a decrease or increase in sales revenues, or changes in the company's financial policy. They are reflected in changed level of inventories, terms of contractors' payment of invoices and terms of payment of liabilities.

In the analysed companies, the share of depreciation in operating cash flows is varied. It is very high in the first two years of the study period. In 2015, the companies made losses and financed operating activities through depreciation. In some companies, depreciation was several times higher than operating cash flow. For example, at Peabody, depreciation was almost 40 times higher in 2015 and in 20168.8 times higher than operating cash flow. This means that the entire depreciation was used to finance operating activities. In 2017-2019, in most companies the share of depreciation in operating cash flows trended upward, which means that the share of the financial result and changes in the demand for net working capital in operating cash flow decreased. In 2019, in JSW SA,

Table 3

Share of Depreciation in Operating Cash Flow in Companies Surveyed in the Years 2015-2019

\begin{tabular}{|c|c|c|c|c|c|}
\hline Company & 2015 & 2016 & 2017 & 2018 & 2019 \\
\hline Anglo American PLC & 59.9 & 39.6 & 29.7 & 36.4 & 36.7 \\
\hline Arch Resources Inc. & 854.3 & 155.7 & 30.9 & 28.6 & 26.7 \\
\hline BHP Group PLC & 38.4 & 36.8 & 34.1 & 32.6 & 38.9 \\
\hline Coal India Ltd. & 21.5 & 17.7 & 14.5 & 21.7 & 74.0 \\
\hline JSW SA & 188.0 & 93.6 & 28.7 & 27.2 & 90.7 \\
\hline LWB SA & 52.8 & 53.2 & 58.3 & 88.1 & 54.1 \\
\hline Mechel PAO & 31.9 & 22.2 & 19.8 & 18.3 & 26.3 \\
\hline Peabody Energy Corp. & 3972.2 & 881.4 & 63.4 & 45.6 & 88.7 \\
\hline Raspadskaya PAO & 42.3 & 24.6 & 12.4 & 13.7 & 14.9 \\
\hline Rio Tinto PLC & 49.5 & 56.6 & 31.5 & 34.0 & 29.4 \\
\hline Vale SA Brazilian & 79.2 & 56.0 & 29.6 & 25.5 & 31.2 \\
\hline Whitehaven Coal Ltd. & 63.5 & 75.9 & 22.0 & 22.8 & 24.5 \\
\hline
\end{tabular}

Source: own calculations based on the balance sheets of mining companies retrieved from a Reuters database 
Peabody, and India Coal, operating cash flows were mainly the result of accrued depreciation. In the remaining companies, this share ranged between $20 \%$ and $50 \%$. Overall, the share of depreciation in operating cash flows in Polish coal companies does not differ significantly from the same in global companies. A stable level of this ratio throughout the study period can be noticed in LWB (60\% on average) and $\mathrm{BPH}$ ( $36 \%$ on average). This confirms the hypothesis assumed in the introduction about the significant role of depreciation in creating operating cash flows.

Table 4 shows the ratio of depreciation to capital expenditure. It reveals what percentage of these expenses are covered by depreciation charged to expenses in a given financial year. Taking the presented ratios into account, the companies can be divided into three groups:

- companies (Coal India, Vale S.A.) in which capital expenditure was higher than depreciation. This means that these entities go beyond mere simple replacement of assets, and instead invest in development as well,

- companies (Mechel PAO, Peobody) whose capital expenditure was several times lower than depreciation throughout the study period. In 2015 Peabody's depreciation was 4.5 times and in 2016 in Mechel PAO's capital expenditure was 3 times than capital expenditure. Depreciation was used to finance operating and financing activities.

- companies with a highly varied share of depreciation in capital expenditure in some years report depreciation below their capital expenditure, while in other years depreciation markedly exceeds such expenditure. This group comprises the Polish coal companies, in which the ratio of depreciation to capital expenditure does not fluctuate so much as in the other analysed companies. For example, in 2015 Australia' Whitehaven Coal's depreciation financed $26 \%$ of capital expenditure, and in 2018 it was $130 \%$ higher than the expenditure. In 2015, JSW SA's capital expenditure was $30 \%$ lower than its depreciation, and in 2019, depreciation financed only $50 \%$ of capital expenditure. Companies that allocated only part of their depreciation to capital expenditure could use the remaining part to pay off their debts. In the last two years of the study period, mining companies significantly reduced their indebtedness. Their assets are financed through equity and spontaneous liabilities.

All in all, depreciation is the main source of coal companies' investment financing. This confirms the

\section{Table 4}

Ratio of Depreciation to Capital Expenditure in the Companies Surveyed in Years 2015-2019

\begin{tabular}{lccccc}
\hline Company & $\mathbf{2 0 1 5}$ & $\mathbf{2 0 1 6}$ & $\mathbf{2 0 1 7}$ & $\mathbf{2 0 1 8}$ & $\mathbf{2 0 1 9}$ \\
\hline Anglo American PLC & 58.7 & 84.4 & 104.9 & 76.4 & 59.3 \\
Arch Resources Inc. & 303.7 & 223.3 & 189.9 & 124.7 & 41.9 \\
BHP Group PLC & 96.1 & 132.6 & 107.4 & 81.8 & 80.0 \\
Coal India Ltd. & 48.8 & 35.3 & 35.9 & 48.9 & 61.1 \\
JSWSA & 130.3 & 84.3 & 111.6 & 60.8 & 50.4 \\
LWB SA & 88.1 & 133.6 & 96.0 & 96.1 & 81.7 \\
Mechel PAO & 273.6 & 289.2 & 196.8 & 246.5 & 241.6 \\
Peabody Energy Corp. & 451.3 & 367.7 & 321.7 & 225.6 & 210.6 \\
Raspadskaya PAO & 122.2 & 110.5 & 83.6 & 92.4 & 71.1 \\
Rio Tinto PLC & 99.1 & 159.2 & 97.6 & 87.6 & 79.9 \\
Vale SA Brazilian & 46.2 & 69.8 & 95.0 & 230.8 & 99.8 \\
Whitehaven Coal Ltd. & 25.9 & 138.7 & 141.5 & 178.7 \\
\hline
\end{tabular}

Source: own calculations based on the balance sheets of mining companies retrieved from a Reuters database 
fourth hypothesis about the importance of depreciation in covering capital needs. The varied use of depreciation to cover capital expenditure results from the economic situation and the market prices for coal. During an economic boom, companies allocate part of their profit to investments and to debt servicing. The role of depreciation in covering these needs then drops. The scope of diversification of coal companies' activities is undoubtedly an important factor influencing the significance of depreciation in covering capital needs. Business cycles in their various areas of activity do not overlap, which results in smoothing their financial results. Another factor is the capital and logistical links between coal mining companies and coal consuming companies. Companies with guaranteed sales are more resilient than companies selling coal on the free market.

\section{Conclusions}

In conclusion, depreciation is a process reflecting the systematic loss of value of exploited fixed assets because of their physical wear and tear or obsolescence. Being a source of financing of a company's fixed assets, depreciation constitutes the company's capital through capital release and reduces tax liabilities. Ultimately, depreciation is put into place to enable simple replacement of assets, and on an ongoing basis it is used to finance operating activities, cover capital expenditure and to pay off debts. The author's empirical research allowed to establish that the level of accumulated depreciation in Polish coal companies is similar to that in global companies. The average annual depreciation rates in Polish companies do not differ significantly from those in global companies, which confirms the first and second research hypotheses.

The share of depreciation in operating cash flows in Polish coal companies was slightly higher than in global companies. At LWB, over the five-year study period, the share of depreciation in operating cash flows remained stable at an average of $60 \%$. At JSW, this share was more volatile and, apart from 2015, averaged $48 \%$. In global companies, it also fluctuated between $20 \%$ and $45 \%$. This corroborates the significant role of depreciation in creating operating cash flows and confirms the third hypothesis assumed in the introduction. In the years when the companies made higher profits, the share of depreciation decreased, while in years of declining profits, in many companies depreciation was higher than their operating cash flow, which indicates that it was used to finance their operating activities. In coal companies, depreciation is the main source of investment financing. Its share in covering capital expenditure ranged from 50 to $100 \%$. In many companies, in some years, depreciation was much higher than the level of capital expenditure, implying that some depreciation was used to pay off debts. Empirical observations of the relationship between depreciation and capital expenditure confirmed the fourth research hypothesis. In summary, depreciation is the capital used to finance operating and investing activities and service debt. Thus, it facilitates the maintenance of liquidity, implementation of investment projects and improves companies' ability to service debt.

\section{References}

Aleszczyk, J. (2012). Rachunkowość finansowa od podstaw, wyd.6 [Financial accounting basics, $6^{\text {th }} \mathrm{Ed}$.]. Zysk i S-ka.

Ackerman, H., Fochman, M., \& Wolf, N. (2016). The effect of straight-line and accelerated depreciation rules on risky investment decisions - An experimental study. International Journal of Financial Studies, 4(19), 1-26. https://doi. org/10.3390/ijfs4040019

Cygańska, M. (2014). Wpływ alternatywnych metod amortyzacji środków trwałych na wynik finansowy, nadwyżkę finansową i obciążenia podatkowe przedsiębiorstwa - analiza przypadku [Impact of alternative methods of fixed assets depreciation on the company's financial result, financial surplus and tax burden - Case study]. Finanse, Rynki Finansowe, Ubezpieczenia, 71, 9-18.

Dobija, M., (2002). Monetary unit - The theory of value. In M. Dobija (Ed.), Monetary unit stability in holistic approach, Leon Koźmiński Academy of Entrepreneuship and Management.

Fan, J., Titman, S., \& Twite, G. (2012). An international comparison of capital structure and debt maturity choices. Journal of Financial and Quantitative Analysis, 47(01), 23-56. https://doi.org/10.1017/ S0022109011000597

Feld, L., Heckemeyer, J., \& Overesch, M. (2013), Capital structure choice and company taxation: A meta-study. Journal of Banking \& Finance, 37(8), 
2850 -2866DOI: 10.1016/j.jbankfin.2013.03.017

Firth, M. (1995). The impact of institutional stockholders and managerial interest on the capital structure of firms. Managerial and Decision Economics, 16(2), 167-175.

Glautier, M., Underdown, B., \& Morris, D. (2011). Accounting: Theory and practice, $8^{\text {th }}$ edition. Financial Times Prentice Hall.

Głodek, Z. (2001). Odpisy amortyzacyjne jako źródło finansowania przedsiębiorstwa [Depreciation provisions as a Source of Corporate Financing], In E. Urbańczyk (Ed.). Zarządzanie wartością przedsiębiorstwa $w$ warunkach globalizacji. Zarzadzanie wartością przedsiębiorstwa $w$ warunkach globalizacji [Managing value of the company in the conditions of globalisation] (pp. 631-635). Wydaw. Nauk. US.

Grabiński, K. (2016). Determinanty kształtowania wyniku finansowego $w$ teorii i praktyce europejskich spótek giełdowych [Determinants of earnings management in the theory and practice of European listed companies]. Wydawnictwo Uniwersytetu Ekonomicznego w Krakowie.

Graham J., \& Harvey, C. (2001). The theory and practice of corporate finance: Evidence from the field. Journal of Financial Economics, 60(2), 187-243. https://doi.org/10.1016/S0304-405X(01)00044-7

Grzywacz, J. (2012). Kapitał w przedsiębiorstwie i jego struktura [Company's capital and its structure]. Oficyna Wydawnicza SGH.

Hendriksen, E., \& van Breda, M. (2002). Teoria rachunkowości [Accounting theory]. WN PWN.

Iwin-Garzyńska, J. (2018). Podatkowy kapitał amortyzacyjny. Zarys problemu [Tax depreciation capital. Outline of the issue]. Studia Ekonomiczne, Zeszyty Naukowe Uniwersytetu Ekonomicznego w Katowicach, 358, 93-102.

Iwin-Garzyńska J. (2005), Kapitał amortyzacyjny w zarzadzaniu [Role of depreciation capital in management]. PWE.

Janasz, K. (2008). Kapitał jako podstawa rozwoju przedsiębiorstwa [Capital as a basis of corporate development]. Studia i Prace Wydziału Nauk Ekonomicznych i Zarządzania US, 1, 69-79.

Leszczyłowska, A. (2018). Znaczenie nieodsetkowych osłon podatkowych dla finansowania dłużnego w warunkach przedsiębiorstw w Polsce [Significance of non-interest tax shields for corporate debt financing in Poland]. Bank i Kredyt, 49(4), 357 -378.

Maruszewska, W. (2018). Zróżnicowane ujęcie amortyzacji w sprawozdawczości finansowej współczesnych przedsiębiorstw [Diversified pre- sentation of depreciation in financial accounting of contemporary companies]. Studia Ekonomiczne. Zeszyty Naukowe Uniwersytetu Ekonomicznego w Katowicach, 389, 137-149.

Mądra-Sawicka, M. (2017). Samofinansowanie inwestycji przedsiębiorstw przetwórstwa spożywczego a poziom ich produktywności [The role of the self-financing of investments in food processing companies versus their productivity level]. Annales Universitatis Mariae Curie-Skłodowska, Sectio H Oeconomia, 51(6), 197-207.

Olejko, K. (2014), Amortyzacja w procesie realizacji założeń polityki rachunkowości przedsiębiorstwa górniczego [Depreciation in the process of implementation of accounting policy assumptions in a mining company]. Studia Ekonomiczne, Zeszyty Naukowe UE $w$ Katowicach, Polityka rachunkowości a kształtowanie wyniku finansowego, (201), 213-214.

Pfaff, J., Poniatowska, L., \& Rówińska, M. (2018). Wykorzystanie instrumentów polityki rachunkowości $w$ wybranych obszarach sprawozdania finansowego [Exploitation of accounting policy tools in selected areas of the financial statement]. Wydawnictwo CeDeWu.

Piketty, T. (2015). Kapitał w XXI wieku [About capital in the twenty-first century]. Wydawnictwo Krytyki Politycznej.

Sigidov, Y., Rybyantseva, M., Adamenko, A., \& Yarushkina, E. (2016). Methodological aspects of depreciation as an economic category. International Journal of Economics and Financial Issues, 6(IS), 88-95.

Sierpińska, M. (2021). Determinants of mining companies' capital structure. Gospodarka Surowcami Mineralnymi - Mineral Resources Management, 37(2), 125 -144. https://doi.org/10.24425/ gsm.2021.137561

Smith, A. (2007). Badania nad natura i przyczynami bogactwa narodów [An inquiry into the nature and causes of the wealth of nations]. WN PWN.

ROZPORZĄDZENIE KOMISJI (UE) NR 1255/2012 z dnia 11 grudnia 2012 r. zmieniające rozporządzenie (WE) nr 1126/2008 przyjmujące określone międzynarodowe standardy rachunkowości zgodnie z rozporządzeniem (WE) nr 1606/2002 Parlamentu Europejskiego i Rady w odniesieniu do Międzynarodowego Standardu Rachunkowości (MSR) 12, Międzynarodowych Standardów Sprawozdawczości Finansowej (MSSF) 1 i 13 oraz Interpretacji Komitetu ds. Interpretacji Międzynarodowej Sprawozdawczości Finansowej 
(KIMSF) 20 Dziennik Urzędowy Unii Europejskiej 29.12.2012, L 360/78 [Commission Regulation (EU) No 1255/2012 of 11 December 2012 amending Regulation (EC) No 1126/2008 adopting certain international accounting standards in accordance with Regulation (EC) No 1606/2002 of the European Parliament and of the Council as regards International Accounting Standard 12, International Financial Reporting Standards 1 and 13, and Interpretation 20 of the International Financial Reporting Interpretations Committee Text with EEA relevance OJ L 360, 29.12.2012]

Ustawa z dnia 15 lutego 1992 r. o podatku dochodowym od osób prawnych [Act of 15 February 1992 on corporate income tax]. https://isap.sejm.gov.pl/ isap.nsf/DocDetails.xsp?id=WDU19920210086

Ustawa z dnia 29 września 1994 r. o rachunkowości, Dz.U. 1994 nr 121 poz. 591 [Act of 29 September 1994 on accounting]. http://isap.sejm.gov.pl/isap. nsf/DocDetails.xsp?id=wdu19941210591

PGE Group Consolidated Reports. https://www.gkpge. pl/Relacje-inwestorskie/dane-finansowe 